\title{
Outpatient parenteral antibiotic therapy (OPAT) in the United States: Delivery models and indications for use
}

\author{
Alan D Tice MD FACP
}

$\mathrm{T}$ he use of intravenous (IV) antibiotic therapy outside hospitals was first reported in the literature in the United States in 1974 (1). What started out with a few children treated with outpatient parenteral antimicrobial therapy (OPAT) for recurrent episodes of pneumonia related to cystic fibrosis grew rapidly to the point where now at least 250,000 patients are treated with OPAT each year in the United States (2). This growth has been brought about by a variety of factors including cost savings, improved technology, long acting antibiotics, patient preference and the leadership of health care professionals. Each community has developed its own systems for providing OPAT, with a variety of providers as well as delivery models. The success of OPAT continues, with a growth rate of $15 \%$ to $20 \%$ each year, which will likely continue into the near future (2).

\section{OPAT ORGANIZATION MODELS}

The organizational structures for OPAT programs in the United States vary considerably $(2,4)$. The predominant infusion provider types in the United States are commercial home infusion companies, which may be local or national. They generally evolve from a pharmacy or a pharmacy-based model and employ nurses. A few OPAT programs have developed from visiting nurse services. Many physicians or physician groups have developed their own programs to treat their own patients in their office or clinic. Often an infectious diseases specialist is in charge of the program to manage patients on OPAT similar to the way an oncologist manages outpatient cancer chemotherapy patients. A growing number of hospitals have developed their own OPAT programs so that they can continue to provide care for the patients previously treated as inpatients. This trend will likely continue if hospitals are to remain the focal point of medical care in communities. No matter what the organizational structure, the most effective and successful OPAT programs function with the combined input from physicians, nurses and pharmacists who must be able to communicate rapidly and function as a team (5).

\section{DELIVERY MODELS FOR OPAT}

There are three basic models for delivery of OPAT: the visiting nurse model; the infusion centre model; and the selfadministration model. Table 1 outlines the different models, and lists the advantages and disadvantages of each (6). The visiting nurse model involves a nurse going to the home to administer the medication. It is appropriate when there is a well-developed home care nursing service and the nurses are trained in intravenous therapies. This model allows the nurse to evaluate the home environment, which may be quite revealing in regards to social and drug or alcohol abuse problems. It is convenient for the patient, but it may be costly, depending on the time that it takes for the nurse to visit the home and travel between residences. The infusion centre model requires 
TABLE 1 OPAT delivery models

\begin{tabular}{|c|c|c|}
\hline Model & Advantages & Disadvantages \\
\hline Visiting nurse & $\begin{array}{l}\text { Opportunity for home } \\
\text { inspection; } \\
\text { supervised } \\
\text { administration; } \\
\text { convenience to } \\
\text { patient }\end{array}$ & $\begin{array}{l}\text { Cost of nurse time } \\
\text { and travel, privacy; } \\
\text { safety of nurse }\end{array}$ \\
\hline Infusion centre & $\begin{array}{l}\text { Medical staff } \\
\text { available; access to } \\
\text { medications and } \\
\text { devices; physician } \\
\text { available; supervised } \\
\text { administration }\end{array}$ & $\begin{array}{l}\text { Cost of facility; } \\
\text { patients must travel } \\
\text { to clinic }\end{array}$ \\
\hline Self-administration & $\begin{array}{l}\text { Reduced staff cost; } \\
\text { reduced facility cost; } \\
\text { patient autonomy }\end{array}$ & $\begin{array}{l}\text { Patient/caregiver } \\
\text { training; } \\
\text { unsupervised } \\
\text { administration; } \\
\text { compliance }\end{array}$ \\
\hline Skilled nursing facility & $\begin{array}{l}\text { Nursing staff always } \\
\text { present; supervised } \\
\text { administration }\end{array}$ & $\begin{array}{l}\text { Cost of facility; } \\
\text { cost of staff }\end{array}$ \\
\hline
\end{tabular}

the patient to travel to a facility to receive their medication. An infusion centre can be established in a hospital clinic, a doctor's office, an emergency department or can even be freestanding $(4,7)$. It offers the advantage of ready access to medicines, medical equipment, and nursing and pharmacy personnel should a problem arise or a change in therapy is needed. In addition, a physician is usually available for immediate evaluation and decision-making as well as routine patient follow-up. This model is less costly because it saves nursing time, but it can be inconvenient or difficult for the patient to travel to the centre daily. The cost of maintaining a facility must also be considered. The self-administration model involves training the patient or caregiver to administer the medication to themselves at home. A variety of options are available for self-administration, from gravity drip bags to computer-operated, battery-powered pumps that allow individual tailoring of the dosing intervals to match the needs of each patient. This model reduces personnel costs as well as facility expenses, but it requires administrative support and more time for education of the patient and their family. There are special challenges involved with self-administration; patients and their caregivers are asked to take an active role in their care and to use sophisticated infusion devices even though they may have little training or knowledge of medicine (7). Generally, patients do well and can help more in self-care than they are given credit for.

It is also possible to provide IV therapy in a skilled nursing facility, which may have nearly the same level of nursing skills as the hospital at less expense. A nursing home may be particularly helpful for a patient with drug or alcohol problems, senility, or an inadequate home situation. The choice of delivery model for OPAT also depends on the experience and resources available. If the organization base is a visiting nurse service, OPAT would likely be provided in the home. If the base is a hospital clinic or a physician's office/clinic, it may be more reasonable to begin with an infusion centre model by converting an examination room into an infusion room or using an empty hospital bed. With time and sufficient volume, the infusion centre can be expanded to provide for training in selfadministration. With any of the models, an infusion centre can be developed to provide expertise in the use of vascular access and infusion devices $(8,9)$.

A fully developed OPAT program should be able to provide any delivery model and be able to switch from one to the other depending on need. For example, a patient may initially need to be seen daily in the office for evaluation or dressing changes of a wound infection; then they can be converted to a self-administration model when they are stable and a prolonged course of IV therapy is needed. For some people, the infusion centre model is preferred because of their fear of modern technology and the reassurance that they feel in coming to see the medical staff at an office or clinic daily.

The antibiotic to be used may also affect which delivery model is used. If an antibiotic is to be dosed more often than every $8 \mathrm{~h}$, the most reasonable model is self-administration using a gravity system or, ideally, a multi-dose pump that can administer the antimicrobial automatically during sleep. If the drug needs to be given bid or tid, the visiting nurse and infusion centre model are possible, but more difficult and depend on the hours that the clinic is open. Fortunately, most infections can be treated with an antimicrobial that can be given once daily $(10,11)$. In the United States, this includes ceftriaxone (12-14), the aminoglycosides $(15,16)$, azithromycin $(17)$, doxycycline (18) and some of the newer quinolone antibiotics $(15,19)$. In the elderly, there is a decline in renal function such that vancomycin should also probably be given once daily $(20,22)$. Amphotericin B and IV pentamidine may also be given on an outpatient basis, but usually the infusion centre model is used because of their toxicity $(23,24)$. Amphotericin $\mathrm{B}$ is commonly given in the author's practice on Monday, Wednesday and Friday, with laboratory studies drawn before the infusion is started and results reported urgently. It is also possible to use ganciclovir or foscarnet to treat or suppress cytomegalovirus infections with once daily dosing $(25,26)$ or to use cidofovir, which needs to be given only every other week $(27,28)$.

In the United States, the choice of infusion provider and delivery model also depends on the payer. There, Medicare, the government health insurance program for the elderly, does not pay for OPAT unless it is provided by a doctor or under a doctor's direct supervision in the office, or in a hospital-based outpatient clinic. Some private insurance companies may refuse to pay for infusion pumps or provide such a low reimbursement that only an infusion centre model is possible. Private insurance companies also have exclusive contracts with specified home infusion providers.

\section{INFECTIONS TO BE TREATED}

The infections that lend themselves to OPAT vary greatly. Initially, the infections treated were those that recurred often, such as those associated with cystic fibrosis (1), or those that required a prolonged course of therapy, such as osteomyelitis 
TABLE 2

Infections treated with outpatient parenteral antibiotic therapy

\begin{tabular}{|c|c|c|c|c|c|}
\hline \multicolumn{2}{|c|}{ Stiver et al (Winnipeg - 1982) (35) } & \multicolumn{2}{|c|}{ Williams Minneapolis, Minnesota-1995) (36) } & \multicolumn{2}{|c|}{ Tice (Tacoma, Washington - 1996) (37) } \\
\hline Infection & Cases & Infection & Cases & Infection & Cases \\
\hline $\begin{array}{l}\text { Osteomyelitis/ } \\
\text { septic arthritis }\end{array}$ & 45 & Cellulitis & 156 & Skin and soft tissue & 270 \\
\hline Endocarditis & 14 & Osteomyelitis & 132 & Osteomyelitis & 14 \\
\hline Pneumonia & 10 & Lyme disease (late stage) & 102 & Septic arthritis & 51 \\
\hline Bacteremia & 9 & Pyelonephritis & 89 & Pelvic infection & 28 \\
\hline Blastomycosis & 6 & Septic arthritis & 68 & Extranodular tissue & 26 \\
\hline Actinomycosis & 2 & & & Respiratory & 20 \\
\hline Soft tissue & 9 & & & Endocarditis & 18 \\
\hline Total & 95 & & 547 & & 527 \\
\hline
\end{tabular}

TABLE 3

Infections amenable to outpatient parenteral antibiotic therapy

\begin{tabular}{lc}
\hline Infections & References \\
\hline Hospitalize first & \\
Meningitis & $41,42,43$ \\
Endocarditis & $30,39,44-47$ \\
$\quad$ Suspected sepsis & 41,48 \\
Acute infections & \\
Cellulitis & $49-52$ \\
Wound infections & $36,38,53,54$ \\
Pneumonia & $31,32,36,40,55-57$ \\
Pyelonephritis & $32,38,58,59$ \\
Chronic infections & \\
Osteomyelitis & $29,47,60-63$ \\
Diabetic foot infections & 64,65 \\
Sinusitis & $36,59,61,66$ \\
HIV-related infection & \\
Cytomegolovirus & $24,38,63,67-69$ \\
Pneumocystis carinii & 70,71 \\
Chronic fungal infections & $60,62,68$ \\
\hline
\end{tabular}

(29), endocarditis (30) or HIV-related cytomegalovirus retinitis (24). These patients were usually hospitalized, stabilized and then discharged early. With time and experience, however, other infections have been treated with early discharge even though their course of therapy may be a week or less. There is also a growing tendency to treat acute infections without hospitalization. This has been possible for pneumonia (31), pyelonephritis (32), and skin and soft tissue infections $(33,34)$.

Table 2 illustrates the variety of infections that have been treated with OPAT by series from Winnipeg, Minneapolis and Tacoma, Washington (35-37). These numbers reflect the ability to treat a wide variety of infections and the transition that has occurred over time to include acute as well as chronic infections. There are an increasing number of reports on the use of OPAT for specific diseases. A list of diseases with references is displayed in Table 3. It now appears that there is no contraindication to OPAT by infection, although patients may need to be hospitalized for other reasons, such as the control of dia-
TABLE 4

Delivery models used by Outpatient Intravenous Infusion Therapy Association centres

\begin{tabular}{llll}
\hline Model & \multicolumn{3}{l}{ Delivery method } \\
\hline Self-administration & $53 \%$ & Gravity & $31 \%$ \\
Infusion centre & $32 \%$ & Syringe pump & $23 \%$ \\
Visiting nurse & $16 \%$ & & \\
& & Computer pump, & $22 \%$ \\
& & Elastomeric pump & $10 \%$ \\
& & Intravenous push & $10 \%$ \\
\hline
\end{tabular}

Information gathered from 19 centres that participated in the OPIVITA registry. They describe the primary delivery model used to treat patients during 1070 courses of therapy during 1997 and 1998

TABLE 5

Infections treated at Outpatient Intravenous Infusion Therapy Association centres

\begin{tabular}{lc}
\hline Infections & Percentage \\
\hline Soft tissue & 24 \\
Bone and joint & 20 \\
Postoperative wound & 9 \\
Septicemia & 5 \\
Endocarditis & 2 \\
\hline
\end{tabular}

Information gathered from 19 centres that provided 1070 courses of therapy over one year

betes, heart disease, wound care, social problems or the need for surgery. Patients with infections such as meningitis, endocarditis and possible sepsis should be hospitalized initially. Even those infections may be treated with OPAT for the last part of IV therapy if they respond promptly and patients are stable (38). Some physicians even routinely treat endocarditis patients without initial hospitalization (39).

\section{REGISTRY OF OPAT PATIENTS}

Information has been collected from OPAT programs in North America. The first data comes from a network of physician-directed OPAT centres that provided information about their patients through a registry organized by the Outpatient Intravenous Infusion Therapy Association (OPIVITA). Nineteen centres across the country provided information during 1997 and 1998. The delivery models used at the centres 
TABLE 6

Sample of patients managed by Infections Limited, Tacoma, Washington, USA (weekend in July 1998)

\begin{tabular}{lclc}
\hline \multicolumn{3}{c}{ Hosptial (39 patients) } & \multicolumn{2}{c}{ Infections } \\
Infection & Patients & \multicolumn{2}{c}{ Clinic (41 patients) } \\
\hline Respiratory & 6 & Osteomyelitis & Patients \\
Osteomyelitis & 6 & Soft tissue & 7 \\
Wound & 5 & Septic arthritis & 6 \\
Bacteremia & 5 & Endocarditis & 5 \\
Abdominal & 4 & Cellulitis & 3 \\
Fever and & 4 & Postoperative & 3 \\
$\quad$ neutropenia & & wound & \\
Postoperative & 3 & Respiratory & 2 \\
$\quad$ wound & & & \\
Cellulitis & 3 & Other & 6 \\
Other & 6 & & 41 \\
Total & 39 & Total & \\
\hline
\end{tabular}

Sample of patients being managed by Infections Limited on intravenous antimicrobial therapy. The sample was taken during a weekend in July 1998

are presented in Table 4 . There was considerable variation among centres, some of which provided exclusively the infusion centre model. The types of infection treated at the centres are presented in Table 5. Again, there was considerable variation among the centres but a relative frequency of infections treated are comparable with the series reported in Table 2.

Infections Limited is an independent, private infectious diseases unit in Tacoma, Washington. The six infectious dis-

\section{REFERENCES}

1. Rucker RW, Harrison GM. Outpatient intravenous medications in the management of cystic fibrosis. Pediatrics 1974;54:358-60.

2. Winters RW. Home infusion therapy industry: an overview. In: Conners RB, Winters RW, eds. Home Infusion Therapy: Current Status and Future Trends. Chicago: American Hospital Publishing Inc, 1995:1-15.

3. Liebert L, Bryant-Wimp J. Ambulatory infusion centers: hospital survival in an outpatient world. Infusion 1997;4:25-9.

4. Nolet BR. Complement or competition? Ambulatory infusion centers are redefining the patient pool for home infusion. Home Health Care 1998; January/February, 72-9.

5. Tice AD. The team concept. Hosp Pract 1993;28(Suppl 1):6-10.

6. Tice AD. Handbook of Outpatient Parenteral Therapy for Infectious Diseases. New York: Scientific American Inc, 1997.

7. Tice AD, Nolet BR. Delivery models for outpatient parenteral antimicrobial therapy. In: Outpatient Parenteral Antimicrobial Therapy: Current Status. New York: Scientific American Inc, 1997:7-11.

8. Tice AD. Intravenous access. In: Handbook of Outpatient Parenteral Therapy for Infectious Diseases. New York: Scientific American Inc, 1997:59-73.

9. Tice AD. Infusion devices. In: Handbook of Outpatient Parenteral Therapy for Infectious Diseases. New York: Scientific American Inc, 1997:75-82.

10. Craig WA. Selecting the antibiotic. Hosp Pract 1993;28(Suppl 1):16-20.

11. Tice AD. Antimicrobial selection for outpatient parenteral antibiotic therapy. In: Handbook of Outpatient Parenteral Therapy for Infectious Diseases. New York: Scientific American Inc, 1997:43-57. eases specialists there provide the majority of infectious diseases care for the community of 500,000 people through both hospital and office care. The OPAT program was started in 1981 with now over 500 patients treated each year through the clinic $(37,40)$. The clinic provides all three delivery models for OPAT and works with several skilled nursing facilities. The most frequently used delivery model is selfadministration followed by the infusion centre model, with only a few nursing visits to the home (37). The Infections Limited program has made a transition from initially hospitalizing all patients before beginning OPAT to starting twothirds of patients directly on OPAT when referrals are made. The Infections Limited OPAT program has developed to the point where the IV antibiotic therapy is usually provided for more outpatients than inpatients. A representative sample of the infections treated by our group in the hospital compared with the clinic is shown in Table 6 . Of significance is the relative frequency of osteomyelitis and HIV-related infections treated in our outpatient program.

\section{CONCLUSIONS}

The types of OPAT programs that have evolved in the United States vary considerably. They are different in terms of organizational structure as well as the models used for delivery. This diversity results from the unique characteristics and interests of each community. In addition, these programs will continue to evolve and respond to the needs and leadership of each community. The infections treated vary with the programs, but there are no contradictions by infection. OPAT continues to provide an opportunity to improve patient care and reduce the cost of care for serious infections.

12. Bradley JS. Once-daily ceftriaxone in the outpatient treatment of paediatric infections. Chemotherapy 1991;37(Suppl 3):3-6.

13. Poretz DM, Woolard D, Eron LJ, Goldenberg RI, Rising J, Sparks S. Outpatient use of ceftriaxone: a cost-benefit analysis. Am J Med 1984;77:77-83.

14. Tice AD. Osteomyelitis. Hosp Pract 1991;26:31-6.

15. MacGowan AP, Bowker KE. Pharmacodynamics of antimicrobial agents and rationale for their dosing. J Chemother 1997;9:64-73.

16. Craig WA. Kinetics of antibiotics in relation to effective and convenient outpatient parenteral therapy. Int J Antimicrob Agents 1995;5:19-22.

17. Luke DR, Foulds G, Cohen SF, Levy B. Safety, toleration, and pharmacokinetics of intravenous azithromycin. Antimicrob Agents Chemother 1996;40:2577-81.

18. Joshi N, Miller DQ. Doxycycline revisited. Arch Intern Med 1997;157:1421-8.

19. Teng R, Harris SC, Nix DE, Schentag JJ, Foulds G, Liston TE. Pharmacokinetics and safety of trovafloxacin (CP-99,219), a new quinolone antibiotic, following administration of single oral doses to healthy male volunteers. J Antimicrob Chemother 1995;36:385-94.

20. Mallet L. Age-related changes in renal function and clinical implications for drug therapy. J Geriatric Drug Therapy 1991;5:5-29.

21. Cooper JW. Anti-infective infusion therapy in the geriatric patient. Infusion 1997;3:10-9.

22. Livornese LL, Benz RL, Ingerman MJ, Santoro J. Antibacterial agents in renal failure. Infect Dis Clin North Am 1995;9:591-614.

23. Gross R, Graziani AL, Laufer D. Adverse effects of the use of 
intravenous pentamidine in the home. Infect Dis Clin Pract 1996;5:456-8.

24. McKinley GF. OPAT in the setting of HIV infection. In: Outpatient Parenteral Antimicrobial Therapy: Current Status New York: Scientific American Inc, 1997;77-80.

25. Sanborn GE, Anand R, Torti RE, et al. Sustained-release ganciclovir therapy for treatment of cytomegalovirus retinitis. Use of an intravitreal device. Arch Ophthalmol 1992;110:188-95.

26. Jacobson MA, O'Donnell JJ, Mills J. Foscarnet treatment of cytomegalovirus retinitis in patients with the acquired immunodeficiency syndrome. Antimicrobial Agents Chemother 1989;33:736-41.

27. Cundy KC, Petty BG, Flaherty J, et al. Clinical pharmokinetics of cidofovir in human immunodeficiency virus-infected patients. Antimicrob Agents Chemother 1995;39:1247-52.

28. Polis MA, Spooner KM, Baird BF, et al. Anticytomegaloviral activity and safety of cidofovir in patients with human immunodeficiency virus infection and cytomegalovirus viruria. Antimicrobial Agents Chemother 1995;39:882-6.

29. Tice AD. Osteomyelitis. In: Outpatient Parenteral Antimicrobial Therapy: Current Status. New York; Scientific American Inc, 1997;55-9.

30. Kunkel MJ. Outpatient treatment of endocarditis. In: Outpatient Parenteral Antimicrobial Therapy: Current Status. New York: Scientific American Inc, 1997;60-4.

31. Fine MJ, Chowdhry T, Ketema A. Outpatient management of community-acquired pneumonia. Hosp Pract 1998; June 15:123-33.

32. Powers RD. The role of the emergency department in OPAT. In: Outpatient Parenteral Antimicrobial Therapy: Current Status. New York: Scientific American Inc, 1997;28-31.

33. Noble WC. Skin and soft-tissue infections. Curr Opin Infect Dis 1996;9:57

34. Poretz DM. Treatment of skin and soft-tissue infections utilizing an outpatient parenteral drug delivery device: a multicenter trial. Am J Med 1994;97:23-7.

35. Stiver HG, Trosky SK, Cote DD, et al. Self-administration of IV antibiotics: an efficient cost-effective home care program. CMAJ 1982;127:207-11.

36. Williams D. Home intravenous antibiotic therapy (HIVAT): indications, patients and antimicrobial agents. Int J Antimicrob Agents 1995;5:3-8.

37. Tice AD. Alternate site infusion: the physician-directed, office-based model. J Intraven Nurs 1996;19:188-93.

38. Tice AD. Infections amenable to outpatient parenteral antimicrobial therapy. In: Handbook of Outpatient Parenteral Therapy for Infectious Diseases. New York: Scientific American Inc, 1997:27-41.

39. Stamboulian D. Outpatient treatment of endocarditis in a clinic-based program in Argentina. Eur J Clin Micro Infect Dis 1995; 14:648-54.

40. Tice AD. An office model of outpatient parenteral antibiotic therapy. Rev Infect Dis 1991;13(Suppl 2):184-8.

41. Bradley JS, Ching DK, Phillips SE. Outpatient therapy of serious pediatric infections with ceftriaxone. Pediatr Infect Dis J 1988;7:160-4.

42. Plotkin SA. Treatment of bacterial meningitis. Pediatrics 1988;81:904-7.

43. Tice AD, Strait K, Ramey R, Hoaglund PA. Outpatient parenteral antimicrobial therapy for central nervous system infections. Clin Infect Dis 1999;29:1394-99.

44. Stiver HG, Telford GO, Mossey JM, et al. Intravenous antibiotic therapy at home. Ann Intern Med 1978;89:690-3.

45. Francioli P, Etienne J, Hoigne R, Thys JP, Gerber A. Treatment of streptococcal endocarditis with a single daily dose of ceftriaxone sodium for 4 weeks. Efficacy and outpatient treatment feasibility. JAMA 1992;267:264-7.

46. Stamboulian D, Bonvehi D, Arevalo C, et al. Antibiotic management of outpatients with endocarditis due to penicillin-susceptible streptococci. Rev Infect Dis 1991;13(Suppl 2):160-3.

47. Durack D. Endocarditis. Hosp Pract 1993;28(Suppl 2):6-9.

48. Grayson ML, Silvers J, Turnidge J. Home intravenous antibiotic therapy: a safe and effective alternative to inpatient care. Med J Aust 1995;162:249-53.

49. Conte RR. Home infusion therapy: treatment of cellutlitis. US Pharmacists Supplement 1994;Oct:9-11.

50. Kind AC, Williams DN, Gibson J. Outpatient intravenous antibiotic therapy. Ten years' experience. Postgrad Med 1985;77:105-8,111.

51. Lindbeck G, Powers R. Cellulitis. Hosp Pract 1993;28(Suppl 2):10-4.

52. Powers RD. Infections of skin and soft tissue. In: Outpatient Parenteral Antimicrobial Therapy: Current Status. New York: Scientific American Inc, 1997;65-8.

53. Deery II HG. Outpatient parenteral anti-infective therapy for skin and soft-tissue infections. Infect Dis Clin North Am 1998;12:935-49.

54. Poretz DM, Eron LJ, Goldenberg RI, et al. Intravenous antibiotic therapy in an outpatient setting. JAMA 1982;248:336-9.

55. Dalovisio JR. OPAT for community-acquired pneumonia. In: Outpatient Parenteral Antimicrobial Therapy: Current Status. New York: Scientific American Inc, 1997;69-72.

56. Williams DN. Reducing hospital costs and stay for pneumonia with home intravenous cefotaxime treatment: results with a computerized ambulatory drug delivery system. Am J Med 1994;27(Suppl 2A):50-5.

57. Tice AD. Experience with a physician-directed, clinic-based program for outpatient parenteral antibiotic therapy in the USA. Eur J Clin Micro Infect Dis 1995;14:23-9.

58. Montalto M. How safe is hospital-in-the-home care? Med J Aust 1998;168:277-80.

59. Poretz DM. The infusion center: a model for outpatient parenteral antibiotic therapy. Rev Infect Dis 1991;13 (Suppl 2):142-6.

60. Hindes R, Winkler C, Kane P, Kunkel M. Outpatient intravenous antibiotic therapy in Medicare patients: cost-savings analysis. Infect Dis Clin Pract 1995;4:211-7.

61. Poretz DM. Outpatient parenteral antibiotic therapy. Int J Antimicrob Agents 1995;5:9-12.

62. Norden C, Gillespie WJ, Nade S. Vertebral osteomyelitis and disk space infection. In: Norden C, Gillespie WJ, Nade S, eds. Infections in bones and joints. Boston: Blackwell Scientific Publications, 1998:231-48.

63. Kayley J, Berendt AR, Snelling MJM, et al. Safe intravenous antibiotic therapy at home: experience of a UK based program. J Antimicrob Chemother 1996;37:1023-9.

64. Fox HR, Karchmer AW. Management of diabetic foot infections, including the use of home intravenous antibiotic therapy. Clin Podiatr Med Surg 1996;13:671-82.

65. Norden CW. Bone and joint infection. Curr Opin Inf Dis 1996;9:109-14.

66. Green SL. Practical guidelines for developing an office-based program for outpatient intravenous therapy. Rev Infect Dis 1991;13(Suppl 2):189-92.

67. Williams DN. Home intravenous antibiotic therapy. Int J Antimicrob Agents 1992;1:253-8.

68. Craig WA. Antibiotic selection factors and description of a hospital-based outpatient antibiotic therapy program in the USA. Eur J Clin Micro Infect Dis 1995;14:4-10.

69. Lim P. Enhancing care with home infusion. Can Nurs J 1995;91:53-5.

70. Yeung KT, Chan M, Chan CK. The safety of i.v. pentamidine administered in an ambulatory setting. Chest 1996;110:136-40.

71. Laufer D, Gross R, Graziani AA, MacGregor R. Use of intravenous pentamidine in the home. IDSA 31st Annual Meeting. New Orleans, October 16 to 18,1993 . (Abst) 


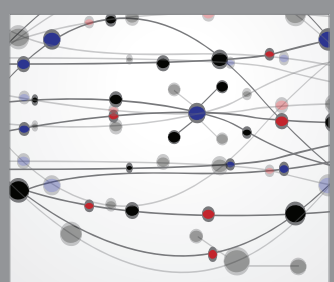

The Scientific World Journal
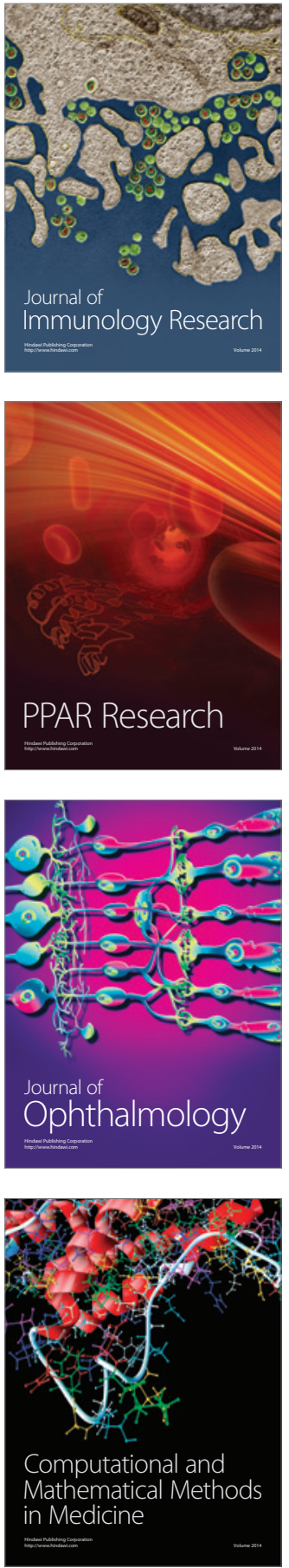

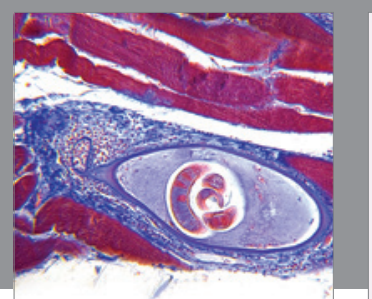

Gastroenterology Research and Practice

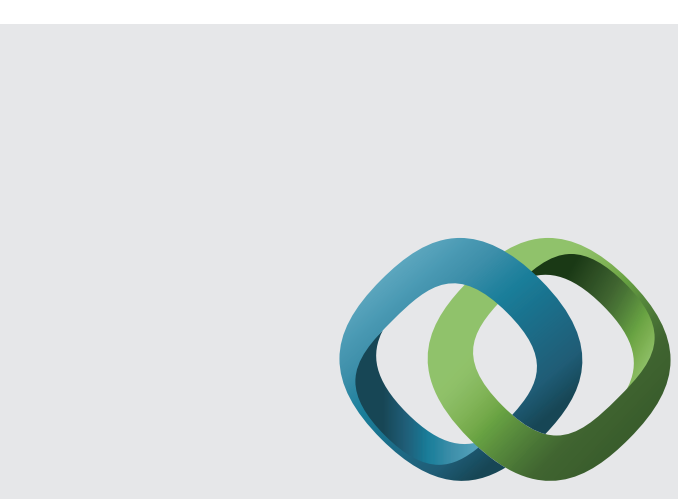

\section{Hindawi}

Submit your manuscripts at

http://www.hindawi.com
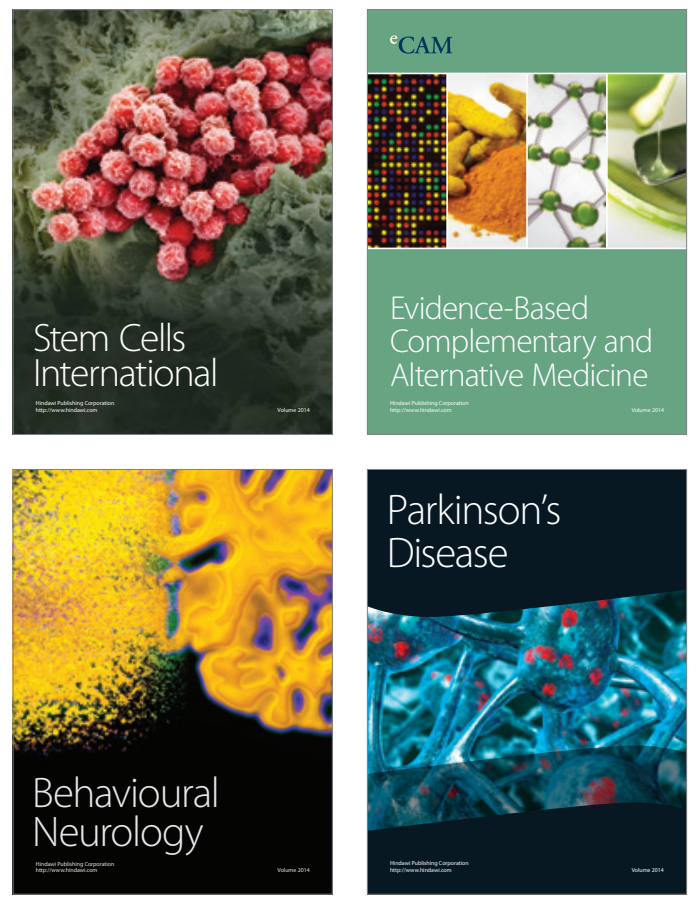
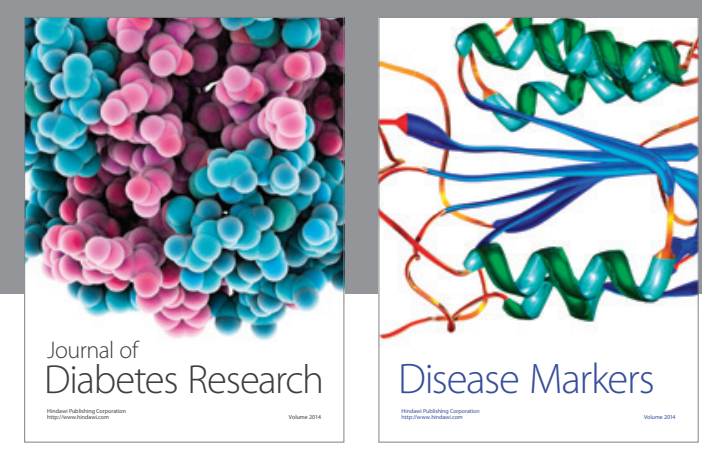

Disease Markers
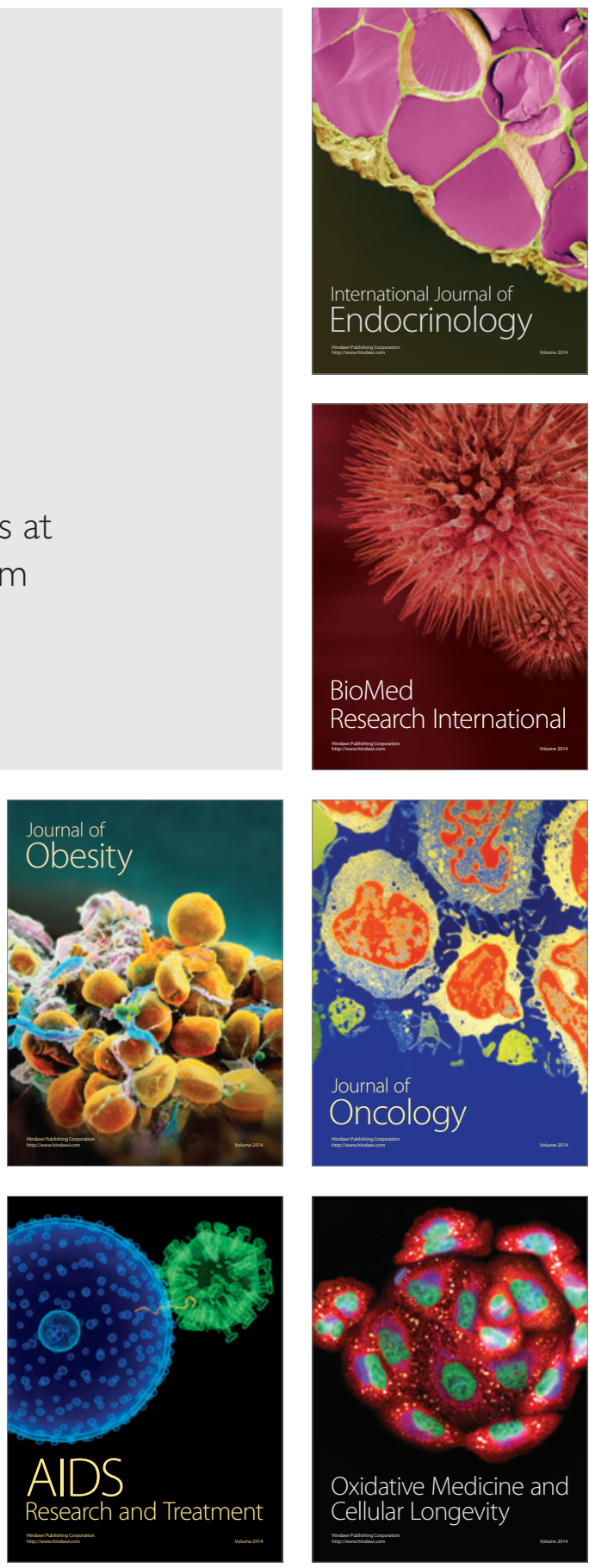